PRINT ISSN 1119-8362

Electronic ISSN 1119-8362
Full-text Available Online at

https://www.ajol.info/index.php/jasem

http://ww.bioline.org.br/ja
J. Appl. Sci. Environ. Manage.

Vol. 24 (8) 1425-1432 August 2020

\title{
In Vitro Assay of Bacterial Load on Some Ruminant Hide and Skin from North Western Nigeria
}

\section{${ }^{*}$ ZUNGUM, IU; ${ }^{2}$ IMAM, TS; ${ }^{3}$ BENJAMIN, B; ${ }^{4}$ MOISULE, A; ${ }^{5}$ DAYA, MG; ${ }^{6}$ ABUBAKAR, T; ${ }^{7}$ BALA, ZM; ${ }^{8}$ PETER, DD}

\author{
${ }^{*}, 4,8$ Department of Biological Sciences, Federal University Gashua, P.M.B 1005, Yobe State - Nigeria \\ ${ }^{2}$ Department of Biological Sciences, Bayero University Kano, P.M.B 1515, Kano State - Nigeria \\ ${ }^{3}$ Department of Biological Sciences, Nigerian Defence Academy Kaduna, P.M.B 2109 Kaduna - Nigeria \\ ${ }^{5}$ Department of Environmental Management and Toxicology, Federal University Dutse, P.M.B 7156 Jigawa State - Nigeria \\ ${ }^{6}$ School of Agriculture and Agricultural Technology, ModibboAdama University of Technology Yola, Adamawa state - Nigeria \\ ${ }^{7}$ Department of Biological Sciences, UsmanuDanfodiyo University, Sokoto P. M. B. 2346, Sokoto State - Nigeria
}

*Corresponding Author Email: idzungum@gmail.com; Tel: +2348030764086

\begin{abstract}
Consumption of meat is considered a vital source of essential amino acids, vitamins and minerals which makes it a critical dietary requirement for humans and other organisms. However, in Sub Saharan Africa, despite accounting for a large chunk of livestock production, it is in short supply due to poverty and cultural practices. Hence, encourages the demand and consumption of other meat products such as singed ruminant hide and skin. This study was carried out to evaluate the effect of singeing on bacterial population of hides and skin of cattle, camel, goat and sheep sold for human consumption in the seven North-western states of Nigeria using standard methods. Data obtained for the bacteria load showed that the highest mean count for singed hides and skins of cattle, camel, goat and sheep mean $\log _{10} \mathrm{CFU} / \mathrm{g} ; 5.10 \pm 0.13,5.08 \pm 0.10,5.06 \pm 0.05$ and $5.05 \pm 0.09$ respectively which were less than the unsigned (control), mean $\log _{10} \mathrm{CFU} / \mathrm{g} 5.71 \pm 0.02,5.70 \pm 0.03,5.71 \pm 0.02$ and $5.69 \pm 0.08$. The high occurrence of bacteria was slightly within unacceptable limits for the ruminant hides and skin sampleslog ${ }_{10} \mathrm{CFU} / \mathrm{g}$; cattle: 5.22 camel: 5.19, goat: 5.23 and sheep: 5.19. This require urgent mitigation as it is slightly contaminated. However, the lower bacterial counts taken for ruminant sampleslog ${ }_{10} \mathrm{CFU} / \mathrm{g}$; cattle: 4.82 , camel: 4.83 , goat: 4.84 and sheep: 4.79 were all within the marginal acceptable standard. Succinctly, $60 \%$ of the ruminant hides and skin samples require correctional measures whereas, $40 \%$ were out rightly contaminated. Hence, urgent action is needed across the abattoirs of Northwestern states of Nigeria to curtail the tide of unsafe hides and skin consumptions. Conclusively, the study established as thus; significantly, Singeing reduces $(\mathrm{p}<0.05)$ the bacterial load on ruminant hides and skin and all samples were considerably high and exceeding the WHO satisfactory level.
\end{abstract}

\section{DOI:https://dx.doi.org/10.4314/jasem.v24i8.18}

Copyright: Copyright $(C) 2020$ Chomini et al. This is an open access article distributed under the Creative Commons Attribution License (CCL), which permits unrestricted use, distribution, and reproduction in any medium, provided the original work is properly cited.

Dates: Received: 30 May 2020; Revised: 03 July 2020; Accepted: 05August 2020

Keywords:Hide and skin, Ruminant, Meat, Singeing, Abattoir and Northwestern Nigeria

Consumption of meat is considered a vital source of essential amino acids, vitamins and minerals which makes it a critical dietary requirement for human and other organisms (Ahmed, 2014). In the least developed countries with high rates of population growth, meat consumption has been growing rapidly, notably in Sub Saharan Africa where ruminant accounts for the bulk of additional consumption in the region (OECD/FAO, 2016). Meanwhile, Sub Saharan Africa despite accounting for large chunk of livestock production, it is in short supply due to poverty and cultural practices which in turn encourages demand and consumption of other Meat products such as hides and skins that is ideally associated with leather industries for production of shoes, bags, belts and other leather works (Leach and Wilson, 2009 and Woko, 2019).
Despite benefits associated with meat, it has been an established conduit for spreading of food-borne ailments due to its high water activity, high protein content, and approximately neutral $\mathrm{pH}$, which create favourable conditions for the thrive and survival of bacteria (Jajaet al., 2018).Singed ruminant hides and skins are generally known as "Ganda" in Northern Nigeria, "Ponmo" in Southern Nigeria and "Welle" in Ghana. It is quite a popular delicacy in several parts of West Africa, and in most West African enclaves within European countries such as the United Kingdom (Mensah et al., 2019). Singeing ruminants proceed in West Africa with application of fuel wood as major fuel supplier and other alternatives such as; scrap tyre, liquefied petroleum gas (LPG), kerosene, hot water, dumped plastics, waste polythene leather 
bags and refuse to singe (Aremo and Omojola, 2018). Slaughtered ruminants such as goats, sheep and cattle are normally singed to get rid of the body hair before consumption and singeing is preferred because it maintains the carcass hides and evokes meat flavours that are highly desired by the consumers (Kalu et al., 2015). However, in Nigeria (NAFDAC) National Agency for Food and Drugs Administration and Control, (26th July, 2019) issued cautionary advice over the consumption of hides and skin for possible chemical contaminations that can post health threats to its consumers.Food borne pathogens are disease causing microbes such as bacteria which contaminates food substances (Addo et al., 2016).Meanwhile, more than 40 different food borne microbes are linked to human illness (US CDC, 2014: Food Poisoning Guide). The Centre for Disease Control and Prevention (CDC) has also estimated that, pathogens account for $81 \%$ of the food borne diseases (Mead et al., 1999). However, the ecology of pathogens varies; some pathogens are pervasive in the natural environment and may contaminate food like meat during processing, distribution and storage (Addo et al., 2016). Animals as food sources such as the ruminants are the major reservoirs for many foodborne pathogens example includes; Escherichia coli, Salmonella species, Campylobacter species, Shigella, Staphylococcus aureus, and Listeria species (Forsythe, 2020).In the developing countries of sub Saharan Africa specifically Nigeria, it is generally recognized that the most significant food-borne hazards from fresh meat are drawn from bacteria, pathogenic bacteria to be precise and can contaminate the environment and cause disease in humans (Bersisa et al., 2019). Some of these, require only a few numbers to trigger food poisoning in humans and the main sources of contamination are the slaughtered animals themselves, the workers and working environment, and to a lesser degree, contamination from air via aerosols and from carcass dressing water (Bell and Hathaway 1996; Birhanu et al., 2017). Moreover, the contaminating organisms are derived mainly from the hide and skin of the animals that comprises of organisms which originates from stomachs and intestines that are excreted in their faeces (Norrung et al., 2009).Similarly, unsafe food containing harmful bacteria causes more than 200 diseases - ranging from diarrhea to fever (WHO, 2019). In tune with this, an estimated 600 million, almost 1 in 10 people in the world fall ill after eating contaminated food and 420000 die every year, resulting in the loss of 33 million healthy life years (DALYs) while children under 5 years of age carry $40 \%$ of the foodborne disease burden, with 125000 deaths every year (WHO, 2019).The risk of toxic substance and pathogenic contamination in meat therefore, is a source of great concern for both public health, and food safety (Forsythe, 2020). Hence, environmental integrity and public safety is required towards engendered enduring economic prosperity and maintenance of a healthy society (Zungum et al., 2019). The study was undertaken to determine the effect of singeing on bacterial population of hides and skin of cattle, camel, goat and sheep sold for consumption in the seven North-western states of Nigeria.

\section{MATERIALS AND METHODS}

Study Area: The study area is Northwestern Nigeria, encompassing the following seven (7) states; Jigawa, Zamfara, Kaduna, Kano, Katsina, Kebbi and Sokoto. The area is found between Latitudes $99^{\circ} 02^{1} \mathrm{~N}$ and $13^{\circ}$ $58^{1} \mathrm{~N}$ and Longitudes $3^{\circ} 08^{1} \mathrm{E}$ and $10^{\circ} 15^{1} \mathrm{E}$ and the area so defined covers a land area of approximately $212,350 \mathrm{~km}^{2}$ (Murtala et al., 2018). It lies within the north-west of Nigeria and shares its borders with Niger Republic to the north, Yobe and Bauchi states to the east, Plateau, Niger, Kwara states to the south and Benin Republic to the west. The major vegetation zones covering the area are Sahel and Sudan savanna with total projected population of $35,915,467$ (NBS, 2018).

Sampling Stations: BirninKebbi modern abattoir, BirninKebbi, Kebbi State, Dutse ultra-modern abattoir situated at the city center of Dutse, Jigawa State, Gusau modern abattoir, Gusau, Zamfara State, Kaduna central abattoir, Zango-Tudun Wada, Kaduna state, Kano abattoir along Wambai quarters, Kano State, Katsina central abattoir, along Dutsinma road, Katsina state and finally, Sokoto modern abattoir, Kara, within Sokoto North, Sokoto state.

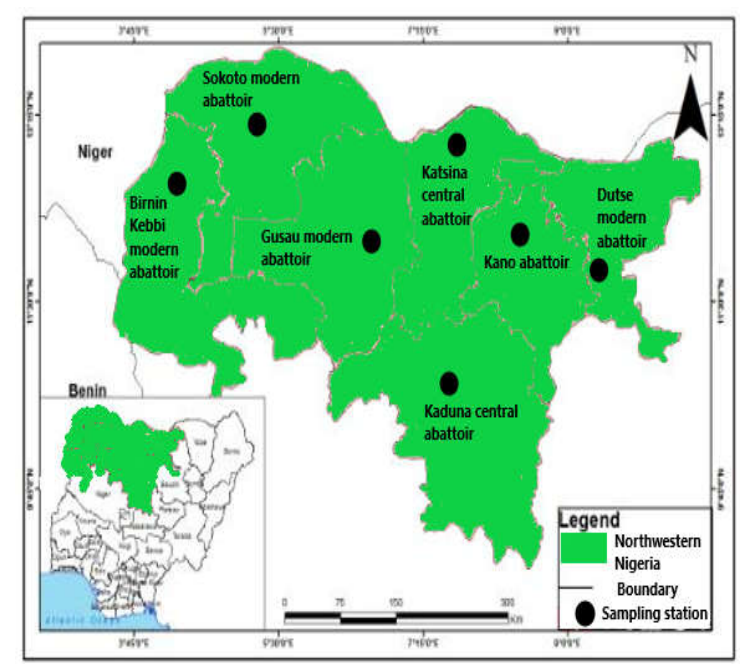

Fig 1. Study area: Map of North western Nigeria showing sampling stations. 
Sample Collection and Preparation: Randomized experimental designed was employed. All samples were aseptically and randomly procured, transported and stored in accordance to microbiological standard procedure (FAO/WHO, 1979). The samples were collected between the period of October and December 2019. Unsigned and singed samples $(50 \mathrm{~g}$ each): where three $(c=5)$ samples were obtained from each type of ruminant within the retail outlets of the seven (7) sample stations. A total of one hundred and sixty (160) samples of hides and skins were collected and comprised of 35 singed and 5 unsinged camel hide, 35 singed and 5 unsinged cattle hides, 35 singed and 5 unsinged goat skin and 35 singed and 5 unsinged Sheep skin. All samples were taken from the neck area of the ruminants and the unsinged samples served as the control and bases for comparison. The samples were inserted in labeled air-tight bags, placed in Insulated plastic ice bucket and transported to Microbiological laboratory of Bayero University Kano for analysis. At the laboratory each sample was chopped to smaller sizes due to its toughness and preserved in a refrigerator at $5-0^{\circ} \mathrm{C}$ prior to analysis.

Preparations of Ruminant hide and skin homogenate: Weighed $25 \mathrm{~g}$ of Ruminant hide and skin sample were aseptically poured into sterile blender jar and added $225 \mathrm{ml}$ of buffered peptone water which were blended together at the speed of $15000 \mathrm{rpm}$ for 2.5 minute to ensure thorough mixture (FAO/WHO, 1979).

Dilution and pour plating: The hides and skins homogenate was thoroughly shaking to mix, syringe was used to pipette $1.0 \mathrm{ml}$ of homogenate which was used to make serial dilution of 5 test tubes containing $9 \mathrm{ml}$ of peptone water; $10^{-1}, 10^{-2}, 10^{-3}, 10^{-4}$ and $10^{-5}$. From the appropriate dilutions, $1.0 \mathrm{ml}$ of the dilution was inoculated into labeled sterilized Petri dish in duplicate plates; nutrient agar was poured into each plate and mixed by rotating. Thereafter, the plates were incubated at $37^{\circ} \mathrm{C}$ for 48 hours after the agar solidified (Bersisa et al., 2019).

Counting colonies and Calculation: Following incubation, dishes containing 30-300 colonies counts were recorded as results per dilution; the average count was taken from colonies in both plates of a dilution and recorded retaining only two significant digits and multiply by the inverse of the corresponding dilution to obtain the number of bacteria Colony Forming Unit per gram (CFU/g) (FAO/WHO, 1979). Furthermore, calculation was undertaken on the results: merging the dilutions to obtain more accurate number of bacteria colony counts in line with the formula given below and in accordance to (FSSAI, 2012):

$$
N=\frac{\Sigma C}{(\mathrm{~N} 1+0.1 \mathrm{~N} 2) \mathrm{D}}
$$

Where $\Sigma \mathrm{C}$ is the sum of colonies counted on all the dishes retained; $\mathrm{N} 1$ is the no. of dishes retained in the first dilution; $\mathrm{N} 2$ is the no. of dishes retained in the second dilution; $\mathrm{D}$ is the dilution factor corresponding to first dilution

The results obtained were expressed in $\log _{10} \mathrm{CFU} / \mathrm{g}$ thereafter, the mean and standard deviations were calculated and tabulated as mean \pm standard deviation $\log _{10}$ CFU/g accordingly (Jaja et al., 2018).

Statistical Analysis: Data analysis was performed using Microsoft $^{\mathrm{B}}$ Excel version 2007, (Microsoft, Redmond, WA, USA) mathematical functions and Statistical Package for Social Sciences (SPSS version 21.0). Descriptive statistics were used to express the mean $\log$, and standard deviation of the aerobic colony counts from the neck hides and skins of carcasses. ANOVA two factor with replication was used to determine the statistical difference in means of singed and unsigned (control) sample. Thereafter, a value of $\mathrm{p}(<0.05)$ was considered significant.

\section{RESULTS AND DISCUSSION}

Determination of the effect of singeing on bacterial population in ruminant hides and skins:The analysis of ruminant hides and skin from seven (7) sample stations for cattle hide as shown in table 1. Had in comparison, the means of the singed against unsigned cattle hide $\left(5.73 \pm 0.00 \log _{10} \mathrm{CFU} / \mathrm{g}\right)$ with statistical significance $p<0.05\left(2.19 \times 10^{-24}\right)$ : there was significant difference in effect of singeing on cattle hides. Hence, there was difference between the singed and unsigned/control cattle hide samples. However, $p$ $>0.05$ (0.38) which indicates: there was no significant difference between the singed cattle hides across the seven different sample stations. The least mean count of singed cattle hide was $4.91 \pm 0.02 \log _{10} \mathrm{CFU} / \mathrm{g}$ and was reported from Kano abattoir. Whereas; the highest was $5.10 \pm 0.13 \log _{10} \mathrm{CFU} / \mathrm{g}$ obtained from Sokoto modern abattoir. Similarly, samples of camel hide had $\mathrm{P}<0.05\left(3.18 \times 10^{-25}\right)$, interpreted as: there was significant difference in effect of singeing on camel hides with regards to presences of mesophilic aerobic bacteria. The least mean count observed was $4.86 \pm 0.02 \log _{10} \mathrm{CFU} / \mathrm{g}$ from Gusau modern abattoir. On the other hand, the highest count taken was $4.92 \pm 0.06 \log _{10} \mathrm{CFU} / \mathrm{g}$ from Dutse ultra-modern abattoir which were all compared against the unsigned /control count, $5.70 \pm 0.03 \log _{10} \mathrm{CFU} /$ gas shown in table 1. 
Table 1.The logarithm $m_{10}$ of mean total bacterial counts for singed and unsigned cattle and camel hide samples obtained from seven sample stations of north western Nigeria

\begin{tabular}{|c|c|c|c|c|}
\hline \multirow{3}{*}{$\begin{array}{l}\mathrm{N}=160, \mathrm{n}=35, \mathrm{c}=5 \\
\text { Sample Station }\end{array}$} & \multicolumn{4}{|c|}{ Mean Aerobic Colony Counts \pm SD $\left(\log _{10} \mathrm{CFU} / \mathrm{g}\right)$} \\
\hline & \multicolumn{2}{|c|}{ Cattle hide } & \multicolumn{2}{|c|}{ Camel hide } \\
\hline & Singed & Unsinged & Singed & Unsinged \\
\hline Dutse ultra-modern abattoir & $4.94 \pm 0.03$ & $5.73 \pm 0.00$ & $4.92 \pm 0.06$ & $5.70 \pm 0.03$ \\
\hline Gusau modern abattoir & $5.05 \pm 0.09$ & $5.73 \pm 0.00$ & $4.86 \pm 0.02$ & $5.70 \pm 0.03$ \\
\hline Kaduna central abattoir & $5.01 \pm 0.01$ & $5.73 \pm 0.00$ & $4.91 \pm 0.02$ & $5.70 \pm 0.03$ \\
\hline Kano abattoir & $4.91 \pm 0.02$ & $5.73 \pm 0.00$ & $4.90 \pm 0.08$ & $5.70 \pm 0.03$ \\
\hline Katsina central abattoir & $5.02 \pm 0.20$ & $5.73 \pm 0.00$ & $5.00 \pm 0.18$ & $5.70 \pm 0.03$ \\
\hline kebbi modern abattoir & $4.98 \pm 0.07$ & $5.73 \pm 0.00$ & $4.88 \pm 0.04$ & $5.70 \pm 0.03$ \\
\hline Sokoto modern abattoir & $5.10 \pm 0.13$ & $5.73 \pm 0.00$ & $5.08 \pm 0.10$ & $5.70 \pm 0.03$ \\
\hline
\end{tabular}

The comparison of the means of singed against unsigned $\left(5.71 \pm 0.02 \log _{10} \mathrm{CFU} / \mathrm{g}\right)$ goat skin has $\mathrm{P}<$ $0.05\left(1 \times 10^{-23}\right)$ indicating there is enough evidence to reject null hypothesis and conclude that there is significant difference in bacteria load between the singed and unsigned/control samples. However, singed goat skin across the sample stations has P-value 0.51 greater than 0.05 indicating sufficient evidence to conclude that there was no significant difference in the samples across the sample stations. Furthermore, the research has $4.94 \pm 0.02 \log _{10} \mathrm{CFU} / \mathrm{g}$ as the least bacterial count obtained at Kaduna central abattoir while, $5.06 \pm 0.05 \log _{10} \mathrm{CFU} / \mathrm{g}$ as the highest bacterial count obtained at Sokoto modern abattoir as presented in table 2. Correspondingly, results from sheep skin samples also show that $\mathrm{P}<0.05\left(1.62 \times 10^{-22}\right)$ indicating there is enough evidence to reject null hypothesis and conclude that there is significant difference in bacteria load between the singed and unsigned/control samples. However, singed sheep skin across the sample stations has P-value 0.67 greater than 0.05 indicating that there is no sufficient evidence to conclude that there was no significant difference in the samples across the sample stations. Furthermore, the research has $4.90 \pm 0.11 \log _{10} \mathrm{CFU} / \mathrm{g}$ as the least bacterial count from Gusau modern abattoir while, $5.05 \pm 0.09 \log _{10} \mathrm{CFU} / \mathrm{g}$ as the highest bacterial count obtained from Sokoto Modern abattoir as shown in table 2. The camel samples were compared against the unsigned hides with $5.69 \pm 0.08 \log _{10} \mathrm{CFU} / \mathrm{g}$ count.

Table 2.The logarithm $\mathrm{m}_{10}$ of mean total bacterial counts for singed and unsigned goat and sheep skin samples obtained from seven sample stations of North western Nigeria

\begin{tabular}{|c|c|c|c|c|}
\hline \multirow{3}{*}{$\begin{array}{l}\mathrm{N}=160, \mathrm{n}=35, \mathrm{c}=5 \\
\text { SAMPLE STATION }\end{array}$} & \multicolumn{4}{|c|}{ Mean Aerobic Colony Counts \pm SD $\left(\log _{10} \mathrm{CFU} / \mathrm{g}\right)$} \\
\hline & \multirow{2}{*}{$\frac{\text { Goat skin }}{\text { Singed }}$} & \multicolumn{2}{|c|}{ Sheep skin } & \multirow[b]{2}{*}{ Unsinged } \\
\hline & & Unsinged & Singed & \\
\hline Dutse ultra-modern abattoir & $4.97 \pm 0.01$ & $5.71 \pm 0.02$ & $4.92 \pm 0.12$ & $5.69 \pm 0.08$ \\
\hline Gusau modern abattoir & $4.90 \pm 0.06$ & $5.71 \pm 0.02$ & $4.90 \pm 0.11$ & $5.69 \pm 0.08$ \\
\hline Kaduna central abattoir & $4.94 \pm 0.02$ & $5.71 \pm 0.02$ & $4.99 \pm 0.05$ & $5.69 \pm 0.08$ \\
\hline Kano abattoir & $5.00 \pm 0.06$ & $5.71 \pm 0.02$ & $5.01 \pm 0.05$ & $5.69 \pm 0.08$ \\
\hline Katsina central abattoir & $5.04 \pm 0.20$ & $5.71 \pm 0.02$ & $4.99 \pm 0.06$ & $5.69 \pm 0.08$ \\
\hline kebbi modern abattoir & $4.96 \pm 0.14$ & $5.71 \pm 0.02$ & $4.93 \pm 0.06$ & $5.69 \pm 0.08$ \\
\hline Sokoto modern abattoir & $5.06 \pm 0.05$ & $5.71 \pm 0.02$ & $5.05 \pm 0.09$ & $5.69 \pm 0.08$ \\
\hline
\end{tabular}

N: Total ruminant sampled; $n$ : Total number of sampled singed and unsigned; Goat $=35$, Sheep =35; SD: Standard deviation; CFU: Colony forming unit; c: number of replication per each sample.

Determination of acceptable level of bacterial contamination in singed ruminant hides and skins: Samples of singed Ruminant hides and skins obtained from the various seven sample stations of North Western Nigeria were compared against WHO microbiology standards in raw meat products which is pegged at $\mathrm{M} \geq 5 \log _{10} \mathrm{CFU} / \mathrm{g}$ : the unsatisfactory whereas, $\mathrm{m} \leq 3.5 \log _{10} \mathrm{CFU} / \mathrm{g}$ : the satisfactory limit and $\mathrm{Mm}>3.5$ but $<5 \log _{10} \mathrm{CFU} / \mathrm{g}$ : the marginally satisfactory limit, this level is acceptable however, a corrective measure is required (WHO, 2007). The results compiled for aerobic colony count of singed ruminant hides and skin samples depicted in table 3.Succinctly recorded (56) $40 \%$ as unsatisfactory while (84) $60 \%$ as marginally satisfactory. Meanwhile, on the individual ruminant samples, the singed cattle hide sample had $49 \%$ in the unacceptable bracket while $51 \%$ within the satisfactory levels. In depth, it had $6.63 \times 10^{4}, 4.82 \log _{10} \mathrm{CFU} / \mathrm{g}$ from Katsina central abattoir as the least and within the marginally satisfactory limits whereas, $1.67 \times 10^{5}, 5.22 \log _{10}$ $\mathrm{CFU} / \mathrm{g}$ from Sokoto modern Abattoir as the highest count and is captured within the unsatisfactory level. The results also for camel hides samples in summary is as thus: $28 \%$ considered unsatisfactory but $71 \%$ of the samples were marginally satisfactory. Meanwhile, both the least and highest bacterial counts were from Katsina central abattoir. In detail, the least bacterial 
count and also within the acceptable category was $6.82 \times 10^{4}, 4.83 \log _{10} \mathrm{CFU} / \mathrm{g}$ while, the highest count was $1.56 \times 10^{5}, 5.19 \log _{10} \mathrm{CFU} / \mathrm{g}$ which on the other hand categorized as unsatisfactory. The goat skin samples had $40 \%$ as unacceptable however, $60 \%$ was marginally satisfactory as shown in table 3 below. The least bacterial count for goat skin was $7.00 \times 10^{4}, 4.84$ $\log _{10}$ CFU/g and recorded in Gusau modern abattoir which is within the marginally satisfactory range but the highest count, $1.81 \times 10^{5} 5.23 \log _{10} \mathrm{CFU} / \mathrm{g}$ was taken from Katsina central abattoir and it is on the unacceptable level. In similar trend, sheep skin samples were found to have $43 \%$ samples exceeding the marginally satisfactory limit but then again, with $57 \%$ of the sample within the acceptable level as captured in table 3 below. The least bacterial count however, was reported as $6.18 \times 10^{4}, 4.79 \log _{10} \mathrm{CFU} / \mathrm{g}$ from Dutse ultra-modern abattoir and it is within the bracket of acceptable limits whereas, the highest counts on the other hand was recorded as $1.16 \times 10^{5}$ ,5.07 $\log _{10} \mathrm{CFU} / \mathrm{g}$ from Kaduna central abattoir.

Table 3. Average number of colony per plate for singed ruminant hide and skin obtained from seven sample stations of North-western

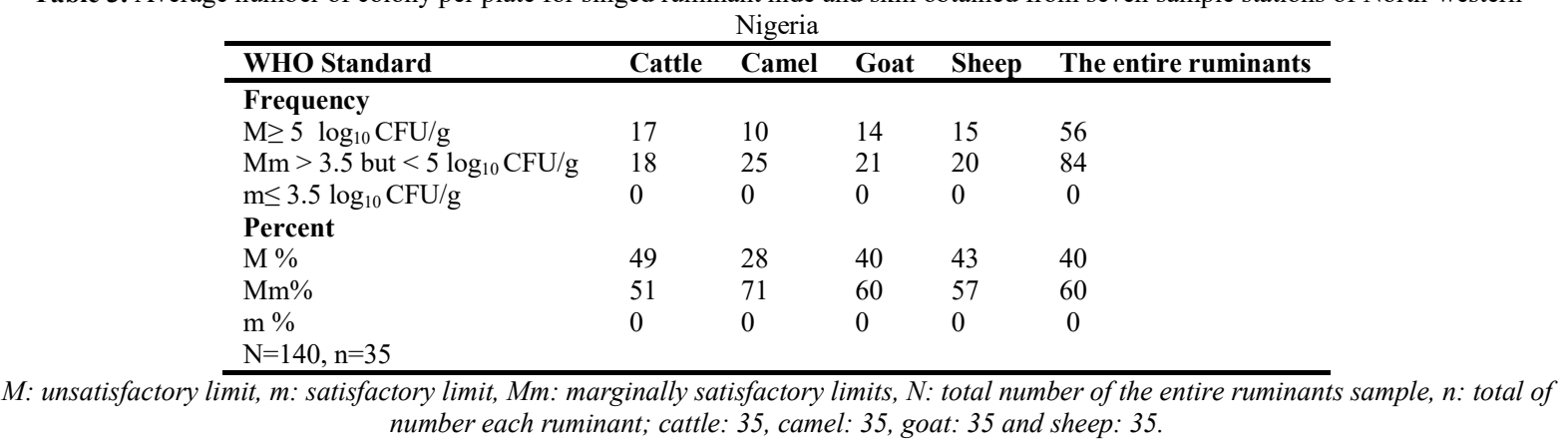

Great number of poor people in low and middleincome Sub Saharan African countries like Nigeria and Ghana are in dire desire of meat substitute to make up for their protein insufficient diets. Hence, the large patronage of ruminant hides and skin from meat processing facilities. However, in the absence of meat safety standards and hygiene, the composition of meat encourages the thriving and growth of microbes to unacceptable levels (Bersisa et al., 2019). Therefore, microbial contaminated meat and other meat products poses grave challenge to public health through transmission of food-borne diseases to consumers (Forsythe, 2020). The prevalence of food-borne diseases is on the rise globally; especially in developing countries such as sub Saharan Africa, where hygiene management systems during meat processing are poorly implemented (Doulgeraki et al., 2012; Zweife et al., 2015; and Hessain et al., 2015). Since major food-borne pathogens dwelling in the gut such as Salmonella, E. coli, Campylobacter, and other Enterobacteria are excreted from the gastrointestinal tract of food-producing animals, cross-contamination is often a result of poor slaughter technique and hygiene standards at abattoirs (Bell and Hathaway, 1996 and Birhanu et al., 2017). Sampling for Microbial estimation in some raw ruminants meats have been conducted in many countries including Namibia, Ireland, Serbia, Switzerland, south Africa, Ethiopia, Ghana and even Nigeria(Nastasijevic et al., 2009; Thomas et al., 2012; Akwetey et al., 2013, Zweife et al., 2015; Fasae and Bakare, 2016 and Jaja et al., 2018). But to our knowledge, none have been conducted on camel hide, and largely on the ruminant hides and skins from Northwestern Nigeria which is a hub for livestock production in Nigeria. The study is timely in the wake of outbreak of novel virus such as; Convic-19 (Corona virus), Ebola and Lassa fever whose emergence and rapid transmission are also associated to food consumption of meat (Gobir et al., 2019; WHO, 2020a; WHO, 2020b). The singed samples from the seven abattoirs of North western Nigeria were below the unsigned (control), thereby, inferring that singeing lessens or even eliminates the bacterial load on ruminant hide and skin(Aniet al.,2018 and Mensah et al., 2019). Despite that, the recorded high score of bacteria count must have been reintroduced during the unhygienic meat processing, washing, transportation or display on the retail sales tables, in line with the revelations of (Olukitibi et al., 2017; Addaiet al., 2019). More so, from the result also, owing to similar meat processing practice, bacterial load count on the ruminant hide and skin samples depicted only slight disparity across the different abattoirs. Meanwhile, the highest mean count for singed cattle and camel hide; mean $\log _{10}$ CFU/g5.10 \pm 0.13 and $5.08 \pm 0.10$ respectively which were less than the unsigned (control), mean $\log _{10}$ $\mathrm{CFU} / \mathrm{g} \quad 5.71 \pm 0.02$ and $5.70 \pm 0.03$ and were comparatively less than $6.3 \pm 2.4$ mean log $\mathrm{CFU} / \mathrm{cm}^{2}$ recorded from informal meat sector of south Africa but higher than that of the formal sector $4.3 \pm 2.5$ mean $\log \mathrm{CFU} / \mathrm{cm}^{2}$ (Jaja et al., 2018), and 
Kano abattoir mean log cfu/ $\mathrm{cm}^{2} 4.4 \pm 0.77$ (Ahmed, 2014).In relation, the highest mean count for goat and sheep skin which were mean $\log _{10}$ CFU/g 5.06 \pm 0.05 and 5.05 \pm 0.09 respectively and consistently, lower than the unsigned (controls),mean $\log _{10}$ $\mathrm{CFU} / \mathrm{g} 5.71 \pm 0.02$ and $5.69 \pm 0.08$ but, was above the findings from both South African formal and informal sector of mean $\log \mathrm{CFU} / \mathrm{cm}^{2} 4.3 \pm 2.5$ and $4.4 \pm 1.1$ separately (Jaja et al., 2018). In the same vein, it was lower than the outcomes from Algeria mean log $\mathrm{CFU} / \mathrm{cm}^{2} 4.48 \pm 0.63$ (Sihamand and Taha, 2009). However, the results corroborated with 5.04mean log $\mathrm{CFU} / \mathrm{cm}^{2}$ from Ethiopia (Bersisa et al., 2019).But, lower than that from Mumbai abattoir in India, mean $\log \mathrm{CFU} / \mathrm{cm}^{2} 5.80 \pm 0.1$ (Sudhakar et al., 2009).

The high occurrence of bacteria within slightly unacceptable limits for the ruminants hide and skins samples $\log _{10} \mathrm{CFU} / \mathrm{g}$; cattle: 5.22 , camel: 5.19 , goat: 5.23 and sheep: 5.19 analyzed, require urgent correctional steps, as it is slightly contaminated, similar to studies in Kano, $\log 10 \mathrm{CFU} / \mathrm{cm}^{2} 5.40$ (Ahmed, 2014), but below $\log _{10} \mathrm{CFU} / \mathrm{cm}^{2} 7.6$ findings in Zaria (Kwaga et al., 1985). Whereas, the lower bacterial counts taken for ruminant samples $\log _{10}$ CFU/g; cattle: 4.82 , camel: 4.83 , goat: 4.84 and sheep: 4.79 were all within the marginally satisfactory levels, though, higher than that of slaughter plants in Canada with counts of $\log \mathrm{CFU} / \mathrm{cm}^{2} ; 3.8,4.2$, and 4.6(Gillet al., 1998).Succinctly, $60 \%$ of the ruminant hides and skin samples require correctional measures whereas, $40 \%$ were contaminated. Hence, urgent action is needed across the abattoirs of Northwestern states of Nigeria to tame tide of unsafe hide and skin consumption.

Conclusion: Singeing reduced microbial population in hides and skins. However, the high microbial load obtained despite singeing, reflects the poor condition of ruminant hides and skins processing, handling, transportation, retail display and inadequate hygienic practices within the seven North-western Nigeria abattoirs. The contamination level though, in lesser percent is a source of concern as it accentuates the perpetual rise of food-borne diseases adding to extant public health and economic burden.

\section{REFERENCE}

Ahmed IB (2014). Bacterial Load and Isolation of Salmonella Species from Cattle Carcasses at Kano

Abattoir- Kano State, Nigeria: A MSPH (Vet) Thesis

Department of Community Medicine, Faculty of Medicine, Ahmadu Bello University, Zaria Nigeria
Addai, TI; Okolocha, EC; Maikai, BV (2019). Bacteriological Quality and Occurrence of Escherichia coli O157:H7 and Salmonella Species in Smoked Rat Meat Sold in Zaria, Nigeria. J. Food Nutri. Sci. 7(2): 25-33 doi: 10.11648/j.jfns.20190702.11

Addo, MG; Acheampong, IA; Akanwariwiak, WG (2016). Assessment of Microbial Quality And Heavy Metal Levels of Raw Cattle Hide and Meat Sold at Retail Outlets in Tarkwa, Ghana. Int. J. Curr. Rese. 8(04):28958-28964, Available online at http://www.journalcra.com

Akwetey, WY; Eremong, DC; Donkoh, A (2013). Chemical and Nutrient Composition of Cattle Hide ("Welle") Using Different Processing Methods. J. Anim. Sci. Adv.3 (4): 176-180.

Aremo. J; Omojola, B (2018). Risk Assessment of Singeing Process for Skin-on Meat Chevon. Conc. Dair. Vet. Sci.1 (4), DOI: 10.32474/CDVS.2018.01.000118.

Bell, RG; Hathaway, SC (1996). The hygienic efficiency of conventional and inverted lamb dressing systems. J. Appl. Bact. 81 (3): 225-234

Bersisa, A; Tulu, D; Negera, C (2019). Investigation of Bacteriological Quality of Meat from Abattoir and Butcher Shops in Bishoftu, Central Ethiopia. Hindawi Inter. $J$. Micro.8,https://doi.org/10.1155/2019/6416803

Birhanu, W; Weldegebriel, S; Bassazin, G; Mitku, F; Birku, L; Tadesse, M (2017). Assessment of microbiological quality and meat handling practices in butcher shops and abattoir found in Gondar town, Ethiopia, Inter. J. Micro-bio. Rese. 8 (2):59-68

Doulgeraki, AI; Ercolini, D; Villani, F; Nychas, GJE (2012). Spoilage microbiota associated to the storage of raw meat in different conditions. Inter. J. Food Micro.157:130-141.

FAO/WHO (1979). Manuals of food Quality control 4. Microbiological analysis: FAO EC/ microbiology/75/report 1/annex V. and bacteriological analytical manual for foods, 1976, $4^{\text {th }}$ Ed. Food and drug administration U.S.A

Fasae, OA; Bakare, MO (2016). Cattle handling, hygiene and slaughtering techniques in selected cattle markets in Abeokuta and environs, Ogun state, Nig. J. Agri. Sci. Environ. 16(2): 50 - 60 
Forsythe, S.J. (2020). The Microbiology of Safe Food. Third edition, Wiley and sons publishers, inc., 111River street, Hoboken, NJ 07030, USA

FSSAI Food Safety and Standards authority of India (2012). Manual of methods analysis of food: Manual on Methods of microbiological testing Lab. Manual 14.

Gill, CO; McGinnis, JC; Bryant, J (1998). Microbial contamination of meat during the skinning of beef carcass hindquarters at three slaughtering plants. Inter. J. food micro. 42:175-84

Grace, D (2015). Food safety in low and middle income countries. Inter. J. Environ. Res. Pub. Heal. 12:10490-10507.

Gobir, AA; Ejembi, CL; Aliyu, AA; Garba, MB; Igboanusi, CJ; Usman, B .(2019). Hygiene Practices in a Nigerian rural Community during Lassa Fever Epidemic. Saudi J. Med. Med. Sci.7:121-3.

Hessain, AM; Al-Arfaj, AA; Zakri, AM; El-Jakee, JK; Al-Zogibi, OG; Hemeg, HA; Ibrahim, IM (2015). Molecular characterization of Escherichia coli O157:H7 recovered from meat and meat products relevant to human health in Riyadh, Saudi Arabia. Saudi J. Bio. Sci. 22:725-729.

Jaja, IF; Green, E; Muchenje, V (2018). Aerobic Mesophilic, Coliform, Escherichia coli, and Staphylococcus aureus Counts of Raw Meat from the Formal and Informal Meat Sectors in South Africa. Inter. J. Environ. Res. Pub. Heal. 15:819;

Kalu E; Nwanta JA; Anaga, AO (2015). Determination of the presence and concentration of heavy metal in cattle hides singed in Nsukka abattoir. J. Vet. Med. Anim. Heal. 1:9-17,

Kwaga. JKP; Umoh, JU; Addo, PB; Belino, ED (1985). Isolation of Salmonellae from lymph nodes of slaughter cattle and market beef in Zaria, Nigeria. Nig. Vet. J. 14: 32-35

Leach, I; Wilson, RT (2009). Higher value addition through hides and skin. Rural Infrastructure and Agro-Industries Division Food and Agriculture Organization of the United Nations Rome, p.1-6

Mead, PS; Slutsker, L; Dietz, V (1999). Food-related Illness and Death in the United States. J. Emer. Infec. Dis. 5 (5): 607-625.
Mensah, NJ; Antwi-Akomeah S; Akanlu, S; Sixtus, BMB; Godfred, SE (2019). Residual Levels of Heavy Metal Contaminants in Cattle Hides Singed with Scrap Tyre and Firewood Fuel Sources: a Comparative Study in the Wa Municipality of Ghana. Amer. J. Environ. Sci. Tech. 3(1):11-21.

Murtala, M; Iguisi, EO; Ibrahim, AA; Yusuf, YO; Inobeme, J (2018). Spatio-temporal analysis of drought occurrence and intensity in northwest zone of Nigeria. Dutse J. Pure Appl. Sci. 4(1) 111-129

NAFDAC National Agency for Food and Drugs Administration and Control on the $\left(26^{\text {th }}\right.$, July 2019). Watch out for the ponmo you buy: NAFDAC alert on the wholesome practice of selling animal hides and skin as food. Retrieved from https://www.nafdac.gov.ng/watch-out-forthe-ponmo-you-buy-nafdac-alert-on-theunwholesome-practice-of-selling-animal-hidesand-skin-as-food/

Nastasijevic, I; Mitrovic, R; Buncic, S (2009). The occurrence of Escherichia coli $\mathrm{O} 157 \mathrm{in} /$ on faeces, carcasses and fresh meats from cattle. Meat Sci. 82:101-105.

NBS National Bureau of statistics, (2018). Demographic Statistics Bulletin 2017, retrieved $1^{\text {st }}$ January, 2020 from https://nigerianstat.gov.ng >download

Norrung, B; Anderson, JK; Buncic, S (2009). Main concerns of pathogenic microorganisms in meat, in Safety of Meat and Processed Meat, F. Toldra, Ed., pp. 3-29, Springer, New York, NY, USA

OECD/FAO (2016). "Meat", in OECD-FAO Agricultural Outlook 2016-2025, OECD Publishing, Paris. DOI: http://dx.doi.org/10.1787/agr_outlook-2016-10$\underline{\text { en }}$

Olukitibi, TA; Adetuyi, FC;Adeleke, BS; Abe, SC (2017). Isolation and Antibiogram of Bacteria Isolated from Processed and Unprocessed CowSkin (Ponmo) in Ogbese Market. J. Adv. Micro. 2(4): $1-8$

Sihamand, N; Taha, M (2009). Superficial bacterial contamination of ovine and bovine carcasses at El-Harrach slaughterhouse, Algeria. Euro. J. Sci. Res. 38(3):474-485 
Sudhakar,G; Bhandare, A; Paturkar, V; Waskar, S; Zende, R (2009). Bacteriological screening of environmental sources of contamination in an abattoir and the meat shops in Mumbai, India. Asian J. Food Agri-Indus. 2(3):280-290

Thomas, KM; McCann, MS; Collery, MM; Logan, A; Whyte, P; McDowell, DA; Duffy, G (2012). Tracking verocyto toxigenic Escherichia coli O157, O26, O111, O103 and O145 in Irish cattle. Inter. J. Food Mic. 153: 288-296.

U.S. CDC. (2014). Food Poisoning Guide Available at http://www.cdc.gov/ncidod/dbmd/diseaseinfo/fo odborneinfections g.htm.Accessedon 14/09/2019

WHO, World Health Organization (2007), Food Safety and Food Borne Illness, World Health Organization Geneva, Switzerland, Fact Sheet no. 237

WHO World health organization, (2019). Food safety: Fact sheet. Retrieved from https://www.who.int/news-room/factsheets/detail/food-safety on 4th, June 2019.

WHOa World health organization,(2020). Fact sheet on Ebola. Retrieved from https://www.who.int/news-room/factsheets/detail/ebola-virus-diseasedisease on 1 st March, 2020

WHOb World health organization,(2020).coronavirus disease 2019(CONVID-19) Situation report-32 retrievedhttps://www.who.int/emergencies/diseas es/novel-coronavirus-2019/technical-

guidance/early-investigationson 1st March, 2020

Woko, Eze Chidozie, (2019). Heavy Metal and Polycyclic Aromatic Hydrocarbon Contents of Cattle Hides Processed by Singeing with Tyre in Aba Abatoir, an MSc Thesis. Department of Biochemistry, Federal University of Technology, Owerri (FUTO) Nigeria

Zungum, IU; Imam, TS; Ahmad, AG; Abubakar, T; Benjamin, B; Daya, MG (2019). Impact of Typha Grass on Biodiversity Loss of Hadejia-Nguru Wetland Located between Jigawa and Yobe States of Nigeria: A review. J. Appl. Sci. Environ. Manage. 23 (10):1847-1853

Zweifel, C; Capek, M; Stephan, R (2014). Microbiological contamination of cattle carcasses at different stages of slaughter in two abattoirs. Meat Sci.98:198-202. 